\title{
Do preeclampsia symptoms resolve after intrauterine death of a fetus?
}

Preeklampsi semptomları fetal ölüm sonrası kaybolur mu?

\author{
Serdar Balcı ${ }^{1}$, Taylan Bodur ${ }^{2}$, Yusuf Aytaç Tohma1, Recep Emre Okyay ${ }^{3}$, Bahadır Saatli ${ }^{3}$, \\ Sabahattin Altunyurt 3 \\ 1Başkent University Faculty of Medicine, Department of Obstetrics and Gynecology, Ankara, Turkey \\ ${ }^{2}$ Muğla Yücelen Hospital, Clinic of Obstetrics and Gynecology, Muğla, Turkey \\ ${ }^{3}$ Dokuz Eylül University Faculty of Medicine, Department of Obstetrics and Gynecology, İzmir, Turkey
}

\begin{abstract}
We present two cases of twin pregnancies without resolution of preeclamptic symptoms after intrauterine death of one twin.

Case 1: A nulliparous woman aged 37 years was referred at 26 weeks of gestation because of arterial hypertension, edema, and growth restriction in one twin. Three weeks later the restricted twin died. During the following three weeks, ultrasound examinations showed a reduced growth velocity of the surviving fetus and reversed umbilical flow. At the end of the $34^{\text {th }}$ week of gestation, cesarean section was performed and a healthy female infant was delivered.

Case 2: A nulliparous woman aged 33 years with a 27-week twin pregnancy was referred because of arterial hypertension and discordant growth. The restricted twin died at 31 weeks of gestation. Following the death, within two weeks the growth of the co-twin started to slow down and reversed end diastolic flow presented. At the end of the 33rd week of gestation, cesarean section was performed and a healthy female infant was delivered.

The interesting point of these cases was the secondary effects on the co-twins. During the time after intrauterine deaths of one twin, the surviving fetuses started to show a reduced growth velocity and reversed umbilical flow and mothers had increased blood pressure and proteinuria again. We think that both cases are evidence of late on-set systemic maternal effects (such as systemic maternal endothelial activation and/or systemic maternal inflammatory response) depends on preeclampsia.
\end{abstract}

Keywords: Preeclampsia, twin pregnancy, growth restriction

$\ddot{\mathrm{O} z}$

İkiz eşinin ölümünden sonra preeklamptik semptomların devam ettiği iki olguyu sunuyoruz.

Olgu 1: Otuz yedi yaşında, nullipar, 26 hafta ikiz gebelik kan basıncı yüksekliği, ödem ve bir fetüste gelişme geriliği nedeniyle kliniğimize refere edildi. Üç hafta sonra geri kalan fetüs öldü. Takip eden üç haftada, ultrason ölçümlerinde yaşayan fetüsün gelişiminde yavaşlama ve umblikal arterde ters akım saptandı. Otuz dördüncü haftanın sonunda sezaryen gerçekleştirildi ve sağlıklı kız bebek doğurtuldu.

Olgu 2: Otuz üç yaşında, nullipar, 27 hafta ikiz gebelik kan basıncı yüksekliği ve bir fetüste gelişme geriliği nedeniyle kliniğimize refere edildi. Otuz birinci gebelik haftasında geri kalan fetüs öldü. Takip eden 2 haftada, ultrason ölçümlerinde yaşayan fetüsün gelişiminde yavaşlama ve umblikal arterde ters akım saptandı. Otuz üçüncü haftanın sonunda sezaryen gerçekleştirildi ve sağlıklı kız bebek doğurtuldu.

Bu olgulardaki ilginç nokta yaşayan ikiz eşlerindeki ikincil etkilerdi. İkiz eşinin ölümünden sonraki periyotta yaşayan fetüste gelişmede yavaşlama, ters umblikal akım ve annede kan basıncında artış ve proteinüri görüldü. Biz bu belirtilerin preeklampsinin geç başlangıçlı sistemik etkilerinin (sistemik maternal endotelyal aktivasyon ve/veya sistemik maternak enflamatuvar yanıt gibi) bir kanıtı olduğunu düşünmekteyiz.

Anahtar Kelimeler: Preeklampsi, ikiz gebelik, gelişme geriliği

\section{Introduction}

Preeclampsia originates from the placenta, and its progressive clinical course is only treated by delivery of the placenta(1). The incidence of disease is 3-5\% and it is known as a major cause of maternal and perinatal mortality(2). Although the etiology and pathogenesis remain to be clarified, termination of pregnancy or delivery of the placenta eradicates the disease; therefore, the placenta is undoubtedly related to preeclampsia(3). Twin gestations occur in $3.2 \%$ of pregnancies and are associated with increased risks of gestational diabetes mellitus, preterm delivery, intrauterine growth restriction, hypertension and hemorrahage (4). Additionally, the risk of preeclampsia in twin pregnancies increases more than twice compared with singleton

Address for Correspondence/Yazıșma Adresi: Serdar Balcı, MD,

Başkent University Faculty of Medicine, Department of Obstetrics and Gynecology, Ankara, Turkey

Phone: +90 5057061988 E-mail: serdarbal@hotmail.com

Received/Geliş Tarihi : 19.01.2016

Accepted/Kabul Tarihi : 20.02.2016 
pregnancies(4). We present two cases of twin pregnancies without resolution of preeclamptic symptoms after the intrauterine death of one twin.

\section{Case Reports}

\section{Case 1}

A nulliparous woman aged 37 years was referred at 26 weeks of gestation because of arterial hypertension, edema, and growth restriction in one twin. On admission her blood pressure was 160/100 mmHg. In our centre, ultrasound examination confirmed growth restriction (weight estimation: $389 \mathrm{~g}$ ) and reversed umbilical flow with cerebral redistribution in one twin, with a normal co-twin (estimated weight: $855 \mathrm{~g}$ ). This was a dichorionic, diamniotic twin pregnancy. The quantitative analysis of proteinuria in a 24-hour urine sample taken after admission showed $2.708 \mathrm{~g} /$ day. To avoid prematurity, expectant management was planned. The patient received alphamethyldopa in a dosage of $1000 \mathrm{mg}$ daily for blood pressure control and magnesium sulfate at a daily dosage of $1500 \mathrm{mg}$ to prevent convulsions. Two days later, because of intolerable nausea and vomiting, we had to stop the magnesium sulfate but we kept going on alpha-methyldopa. During the following three weeks, the blood pressure was under partial control, ultrasound examinations showed no evidence of growth of the restricted twin and confirmed severe doppler abnormalities; the co-twin's assessment was reassuring. Some days later restricted twin died but doppler flows of the surviving twin were normal. Accordingly, we decided to prolong the pregnancy under close observation. Significant proteinuria occured again at 31 weeks of gestation, accompanied by a rise in blood pressure. During the following three weeks, ultrasound examinations showed a reduced growth velocity of the surviving fetus and reversed umbilical flow. At the end of the 34th week of gestation, cesarean section was performed and a healthy female infant weighing $1670 \mathrm{~g}$ was delivered, followed by a macerated female fetus of nearly $200 \mathrm{~g}$. The mother recoverd quickly and her blood pressure was normal on the third day postpartum.

\section{Case 2}

A nulliparous woman aged 33 years with a 27 -week twin pregnancy was referred because of arterial hypertension and discordant growth. On admission her blood pressure was 170/105 mmHg. Our ultrasound check showed growth restriction (weight estimation: $698 \mathrm{~g}$ ) and reversed umbilical flow in one twin, with a normal co-twin (estimated weight: $1.060 \mathrm{~g})$. The examination also revealed a dichorionic, diamniotic twin pregnancy. In a 24-hour urine sample showed proteinuria (4.850 g/day). Expectant management was planned to prevent prematurity. The patient received alpha-methyldopa in a daily dosage of $1000 \mathrm{mg}$ for blood pressure control and magnesium sulfate at a dosage of 1500 mg daily to prevent convulsions. During the following two weeks, beside the partial blood pressure control, ultrasound examinations revealed no growth in the restricted twin and abnormal umblical artery flow; the co-twin's assessment was good. At 31 weeks of gestation, the restricted twin died and a significant proteinuria ( $6.650 \mathrm{~g} /$ day) reappeared but the cotwins doppler flows were normal. Following the death, growth of co-twin started to draw back within two weeks and reversed end diastolic flow presented. At the end of the $33^{\mathrm{rd}}$ week of gestation, cesarean section was performed and a healthy female infant weighing $1.370 \mathrm{~g}$ was delivered, followed by a macerated female fetus of almost $800 \mathrm{~g}$. We discharged the mother from hospital after her blood pressure normalized on the fourth day postpartum.

\section{Discussion}

It is certain that the placenta takes a central role in the pathogenesis of preeclampsia. The importance of poor placentation as a feature of the disorder is well documented(5). However, we still do not know the reasons of poor placentation. In these cases there are two separate placentas. One of them is preeclamptic, the pathologic report documented low weights with fibrin and thrombosis inside the vessels, and the others were normal. We still do not know why one of the twin placentas has abnormal development when both have the same maternal factors such as immunity or blood pressure. One explanation is local factors such as fetus or placental localization, which could possibly affect placental growth.

Another interesting point of these cases was the secondary effects on the co-twins. After intrauterine deaths of one twin, the surviving fetuses started to show a reduced growth velocity and reversed umblical flow and the mothers had increased blood pressure and proteinuria again. We think that this is evidence of late on-set systemic maternal effects such as systemic maternal endothelial activation and/or systemic maternal inflammatory response) depends on preeclampsia.

Usually preeclampsia progresses without any recovery until birth. Few cases of resolution of preeclampsia after spontaneous intrauterine death of one twin or selective termination of a dichorionic pregnancy have been reported(1,6,7). Narasimhulu et al. (8) reported resolution of superimposed preeclampsia in a surviving fetus after the intrauterine demise of its co-twin and suggested that placental involution after fetal demise was the key to resolution of preeclampsia (resolution period take 1 to 3 weeks). However, according to our cases, even if the fetus dies, preeclampsia could not be curable unless placental seperation occurred. The greatest disparity of our cases compared with those in the literature was the amount of proteinuria, nearly 5 g/day in 24-hour urine sample. Consequently, severe preeclampsia may differ from mild preeclampsia, without any resolution or resolution in longer time (more than 3 weeks). In addition, a retrospective analysis of outcomes in pregnant women who had expectant managemant with severe preeclampsia at less than 27 weeks' gestation revealed that overall perinatal survival was $57 \%$ (9\% of them were 
multifetal gestations)(9). As a result, resolution of preeclampsia in dichorionic twin pregnancies following intrauterine death of restricted fetus is still uncertain, especially in severe preeclampsia.

To our knowledge, these are the first cases to describe the return of preeclamptic symptoms in twins after the intrauterine death of one twin in the literature. Further studies are needed for the comprehension of preeclampsia and recognition of placental factors responsible for the persistence of the disease.

\section{Ethics}

Ethics Committee Approval: The study were approved by the Dokuz Eylül University of Local Ethics Committee, Informed Consent: Consnt form was filled out by all participants.

Peer-review: Externally peer-reviewed.

\section{Authorship Contributions}

Surgical and Medical Practices: Bahadır Saatli, Sabahattin Altınyurt, Concept: Taylan Bodur, Design: Serdar Balcl, Data Collection or Processing: Serdar Balc1, Analysis or Interpretation: Recep Emre Okyay, Literature Search: Yusuf Aytaç Tohma, Writing: Serdar Balct. Conflict of Interest: No conflict of interest was declared by the authors.

Financial Disclosure: The authors declared that this study has received no financial support.

\section{References}

1. Bschierl Frank, Beinder E. Temporary resolution of preeclamptic symptoms after intrauterine death of one twin. Hypertens Pregnancy 2005;24:313-7.

2. Audibert F, Salomon LJ, Castaigne-Meary V, Alves K, Frydman R. Selective termination of a twin pregnancy as a treatment of severe pre-eclampsia. BJOG 2003;110:68-9.

3. Brown MA. The physiology of pre-eclampsia. Clin Exp Pharmacol Physiol 1995;22:781-91.

4 Sparks TN, Cheng YW, Phan N, Caughey AB. Does risk of preeclampsia differ by twin chorionicity? J Matern Fetal Neonatal Med 2013;26:1273-7.

5. Redmana CW, Sargent IL. Pre-eclampsia, the placenta and the maternal systemic inflammatory response-a review. Placenta 2003;24(Suppl A):21-7.

6. Sarhanis P, Pugh DH. Resolution of pre-eclampsia following intrauterine death of one twin. Br J Obstet Gynaecol 1992;99:159-60.

7. Hagay ZJ, Levy R, Zalel Y, Weissman A. Single fetal demise in twin gestation resulting in the resolution of severe pre-eclampsia. Eur J Obstet Gynecol Reprod Biol 1994;56:137-8.

8. Narasimhulu DM, Karakash S, Rankin L, Minkoff H. Resolution of superimposed pre-eclampsia, and improvement in umbilical artery flow in a surviving twin after intrauterine demise of its co-twin. J Obstet Gynaecol Res 2015;41:1473-7.

9. Bombrys AE, Barton JR, Nowacki EA, Habli M, Pinder L, How H, et al. Expectant management of severe preeclampsia at less than 27 weeks' gestation: maternal and perinatal outcomes according to gestational age by weeks at onset of expectant management. Am J Obstet Gynecol 2008;199:247. 